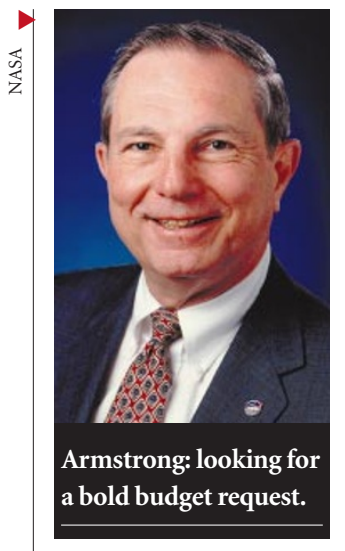

budget designers to be "reasonably bold" in their request.

Another variable is the US presidential election in November. President Bill Clinton's administration will prepare the next federal budget before then, but Congress will not take it up until after the new administration proposes any adjustments.

But some observers are optimistic. "Armstrong has already come to us and asked our membership for ideas and advice," says Jacques L'Heureux, director of University Relations for Space Sciences at the Universities Space Research Association. "He seems very serious."

University researchers have been "very receptive", says Correll. But, he adds, "the biggest fear, as you might expect, is that when the government says 'we're here to help', the feeling is that talk is easy". thttp://www.hq.nasa.gov/office/codea/codeac/ www/news.html

\title{
Germline gene therapy needs tight control, says US panel
}

Paul Smaglik, Washington

Tight regulation and oversight will be needed of efforts to make genetic modifications to human cells that can be passed on to offspring, a panel set up by the American Association for the Advancement of Sciences said this week.

Proponents of germline gene therapy have previously asked that it should not be regulated more heavily than other kinds of experimental medicine (see Nature 392,317; 1998). Such a move, they argue, could slow efforts to develop germline gene therapy, which aims to combat genetic diseases by targeting cells in a prospective parents' testes or ovaries, or by conducting gene therapy on an embryo.

But the recommendation of the AAAS panel reflects its conclusion that, for all its promises, germline therapy remains problematic because unintended genetic changes could be passed to a new child along with intended benefits.

"There would need to be compelling scientific evidence to prove that these procedures are safe and effective," says Mark
Frankel, the report's co-author and director of the AAAS Scientific Freedom, Responsibility and Law programme. Such evidence has not yet materialized.

Rather than pursuing germline therapy, the AAAS report urges scientists to focus on making changes in cells that will not be passed to the next generation. It also encourages more research into methods to correct genetic 'misspellings'.

Without first improving either of those two approaches, germline gene therapy can be neither safe nor effective, Audrey Chapman, director of an AAAS program on biomedical ethics and a co-author of the report, said at a press conference on Monday.

Robert Cook-Deegan, a Georgetown University bioethicist, called for a new body to be set up to monitor germ line gene therapy experiments in animals, perhaps modelled on the National Institute of Health's Recombinant DNA Advisory Committee (RAC). It would eventually decide whether human clinical trials should go forward.

| http://www.aaas.org/spp/dspp/sfrl/germline/main.htm

\section{Case of the stolen Enigma machine takes cryptic turn}

Natasha Loder, London

It is a riddle wrapped in a mystery inside an Enigma. Who stole a rare version of the machine that the Germans used to encrypt military secrets during the Second World War? And does an anonymous note contain a coded clue to the thief's identity?

The 'Enigma machine' was stolen in April from Bletchley Park Museum in Buckinghamshire. During the war, Bletchley Park was home to a team of mathematicians and cryptographers who worked on cracking coded German military communications.

In the past weeks the museum has received two strangely worded, anonymous letters offering to return the machine for a five-figure sum. The first starts: "I have been asked by the current owner the above Enigma machine, who purchased it in good faith (in good faith being the operative words) to say and tell you now today, the unwitting person have no desire of depraving [sic] your august self or any one the pleasure to see it again." It was sent from the Midlands of England, and appears to have been written on a typewriter dating from the Second World War.

The museum's chief executive, Christine Large, says the episode has "an element of mystique which is completely in keeping

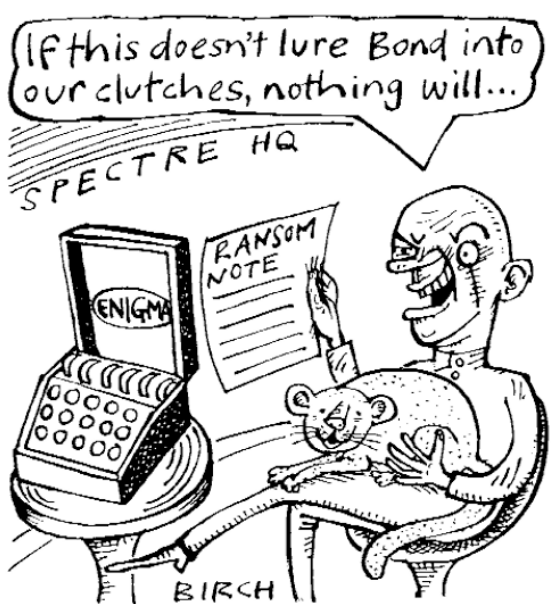

with the history of the park. It is an unusual letter but seems genuine. It doesn't surprise me that the author is a middleman. We really want to assure them that our priority remains getting [the machine] back in good condition."

The museum is now waiting for the next contact. "We have made it very clear that, assuming there is no criminality involved, that police will not prosecute," says Large. The machine was on long-term loan from the Government Communications Head- quarters in Cheltenham, which acquired it after the war.

There are several hundred Enigma machines on the market. But the stolen one, which carries the serial code G 312, is a very rare four-rotor machine used by the Abwehr German military intelligence. The only other known example is owned by the US National Security Agency.

Bletchley Park became the home to the UK Government Code and Cypher School in 1939; the teams that worked to crack the Enigma machines were housed in wooden huts. The Germans updated the machines over the years, but a series of breakthroughs by cryptographers meant that German messages could be decoded for much of the war.

The Buckinghamshire police say the letters are their best lead so far. The first letter ends in a word - which is not being released by police - that some have suggested may be in code. But Large says that the word is recognizable, although not English. The machine featured in an Interpol 'wanted' poster in June, but the police say they have no evidence that it has left the country.

http://www.bletchleypark.org.uk

http://www.interpol.int/public/workofart/ data/1003/1003713.asp

NATURE $\mid$ VOL 407 21 SEPTEMBER 2000 |www.nature.com 